\title{
Worth of watersheds: a producer surplus approach for valuing drought mitigation in Eastern Indonesia
}

\author{
SUBHRENDU K. PATTANAYAK \\ Center for Economics Research, Research Triangle Institute, Research \\ Triangle Park, NC 27709-2194, USA. Email: subrendu@rti.org
}

\author{
RANDALL A. KRAMER \\ Nicholas School of Environment, Duke University
}

\begin{abstract}
This study combines hydrological modeling with applied micro-econometric techniques to value a complex ecosystem service: drought mitigation provided by tropical forested watersheds to agrarian communities. Spatial variation in current baseflow allows estimation of drought mitigation values as the marginal profit accruing to agricultural households. The paper shows that this uncommon focus on producer (not consumer) surplus measures is appropriate for valuation as long as markets for commodities related to the environmental services are complete. For the typical household, the estimated marginal profit is positive, validating the central hypothesis that baseflow makes positive contributions to agricultural profits. There is some evidence, however, that increased watershed protection will increase profits through greater baseflow only in watersheds with a unique mix of physio-graphic and climatic features. The paper evaluates and provides some support for the hypothesis, put forward by hydrological science and the Indonesian Government, that protected watersheds can supply latent and unrecognized ecosystem services to local people.
\end{abstract}

Keywords: Economic-ecological modeling, watershed protection, drought mitigation, valuation, profits, producers surplus, tropical deforestation, Indonesian National Parks. JEL: Q2, Q12, H41

\section{Introduction}

Rapid disappearance of the world's natural forest cover, at an estimated net loss of 56.3 million hectares between 1990 and 1995, endangers the flow

The authors gratefully acknowledge insightful comments from Erin Sills, Kerry Smith, and two anonymous reviewers. Suggestions from seminar participants at Camp Resources IV (Wilmington, NC), 1997 AERE Workshop (Annapolis, MD), Binghamton University, Rutgers University, Research Triangle Institute, University of Louvain (Belgium), and 1998 AAEA Meetings (Salt Lake City, UT) were also greatly appreciated. Field support from Frans Dabukke, Aris Priyanto, Nining N.P., Sastrawan Manullang, Leo Lega, Bill Buffum and student interviewers was invaluable. Data for this paper are drawn from a larger project funded by the Asian Development Bank, the Government of Indonesia, Duke University, the Howard Gilman Foundation and the Joshua Trent Foundation. 
of socially useful goods and services from standing forests, e.g. timber, fuelwood, fodder, herbs, medicines, erosion control, and mitigation of floods and droughts. Economists diagnose this situation as symptomatic of distorted or missing signals, i.e. individual economic agents and policy makers are receiving unreliable and incorrect information regarding the value of goods and services from tropical forests (Panayotou, 1992). This argument has moved beyond the textbooks and seminars of economists and is now widely accepted in international policy circles (Interagency Partnership on Forests, 1997). Watershed services provided by protected tropical forests are good examples of unpriced and undervalued 'life support services' resulting from natural ecosystem functions (Freeman, 1996; Barbier, 1994). A watershed service can be defined as the improvement or maintenance of the ecological characteristics of the watershed that results from soil and water conserving land uses. Dixon's (1997) summary of ecosystem services from protected watersheds includes stabilization of hydrological regimes (mitigating floods and droughts) and control of soil erosion and sedimentation. In many tropical settings the primary contribution of these services is as inputs to agricultural production.

Because the market mechanism will not ensure optimum allocation of watershed services, public intervention to protect tropical forest watersheds is necessary. ${ }^{1}$ While Dasgupta's (1996) contention that the 'rural poor are especially dependent' on such resources adds urgency to the need for government action, the level of watershed services that should be provided directly or indirectly by the government depends on the net benefits of providing these services. Recent surveys of valuation studies reveal that the economic benefits of protected watersheds are rarely quantified (Georgiou et al., 1997; Dixon, 1997). Typically analysis of watershed services have concentrated on soil erosion effects.

This paper addresses this gap in the literature by applying micro-econometric methods, based on conventional producer welfare theory, to the valuation of drought mitigation services from protected watersheds. ${ }^{2}$ The study also responds to recent criticisms of the Dasgupta logic that argue that 'evidence about the role of natural resources is anecdotal, conceptual or based on simulations rather than econometrics' and that 'regressions that might include environmental quality as an input to a production function are rarely part of this literature' (Horowitz, 1998, pp. 1529-30). The focus on producer surplus measures is different from most environmental valuation, which is typically structured on the theory of consumer welfare.

${ }^{1}$ Quasi-public good, externality, and high transaction cost aspects of watershed services prevent them from being traded in any market. Hence missing or distorted signals are not surprising.

${ }^{2}$ While acknowledging the subtle differences between the terms 'value' and 'benefit', we use them interchangeably throughout this paper. We do not claim to perform a comprehensive cost-benefit analysis of watershed protection; instead we focus on the estimation of the benefits or values of watershed services. Estimation of forest protection costs, including expenditures on management and enforcement, and opportunity costs, are relatively straightforward because they constitute market goods and services. In comparison, the non-market nature of watershed services complicates the estimation of benefits. 
We contribute to the theory of valuation by deriving the theoretical conditions under which changes in producer surplus are correct measures of value to beneficiaries who are producer-consumer households. The study is also unique in its empirical application to forested watersheds in a poor agrarian region of a developing country: Manggarai, Indonesia.

Although forests in the highest watersheds of the Manggarai region on the island of Flores had enjoyed some protection since the Dutch colonial rule, the government of Indonesia established Ruteng Park on 32,000 hectares in 1993. The primary conservation goal was to provide greater protection against deforestation threats and to initiate reforestation and land conservation that enhances watershed protection. A recent evaluation of water resources in the region finds that forests in Manggarai provide drought mitigation service by protecting streams and rivers (Binnies and Partners, 1994). Three other studies support this finding. First, research by a local non-governmental organization finds that during the previous 25year period, streamflow has decreased in nine out of ten streams studied in regions of Manggarai that are experiencing deforestation (Swiss Intercooperation, 1996). Second, analysis of cross-sectional variation in hydrological, topographic, and vegetation data from the 37 principal watersheds within Ruteng Park shows that 'reforestation has an important role to ... increase ground water replenishment and springs and river discharge during the dry period' (Priyanto, 1996, ix). Finally, survey findings show that the Manggarai people living around Ruteng Park believe that the protection of their water supply is a primary benefit of the park (Kramer et al. 1997). Thus, while there is substantial bio-physical evidence of the drought mitigation services of Ruteng Park to the farmers downstream from the park, the economic values of this service are unknown. Next we propose an adaptation of Gregersen et al.'s (1987) three-stage framework to estimate the economic value of this drought mitigation service.

In the first stage, we propose that the establishment of Ruteng Park produces a drought mitigation service that is measured as a change in baseflow, where baseflow is the non-episodic residual streamflow that is left over after rain has gone out of the hydrological system in the form of either stormflow (runoff) or evapotranspiration. ${ }^{3}$ While the effect of forested watersheds on the hydrological cycle is complicated, stormflow and evapotranspiration are the two most important components of the hydrological system affected by forests. The effects on evapotranspiration and baseflow are determined primarily by the geometry of the forest canopy, the eco-physiology of the dominant tree species, the litter layer, and the below ground soil structure of forests. These characteristics deter-

\footnotetext{
${ }^{3}$ By park we mean the forests protected by the policy mandate that is institutionalized in the form of a park. So drought mitigation results from the creation of the park that protects the forests. One reviewer observed that it is possible to have 'partial parks' that correspond to varying degrees of forest protection. By way of a preview, this observation is consistent with our findings (reported in section 5) that less than complete (100 per cent) forest cover may be the optimum amount of protection.
} 
mine whether forests are net consumers or net producers of baseflow in a hydrological system (Bruijnzeel, 1990). The park management believes that 'revegetation for water conservation will reduce run off during the rainy season and increase infiltration' (Indonesian Ministry of Forestry, 1995, vol II, p. 5). The forest hydrology literature posits that extensive tree cover helps maintain baseflow levels in areas with environmental characteristics similar to Ruteng, i.e. steep terrain, intense rainfall, and clayey and compacted soil (Bonnell and Balek, 1993). The three forest hydrology studies discussed in the previous paragraph suggest that in many Manggarai watersheds, forests are net producers of baseflow.

In the second stage, given that agriculture is the predominant economic activity in the region and because the farmers who benefit from this service cannot choose the quantity and quality of forest protection that mitigates drought, the primary economic role of baseflow is as a fixed input in agricultural production. In this context, baseflow can be conceived as the part of the hydrological cycle that is useful in farming: moisture available to plants.

Finally in the third stage, the effect on agricultural production changes the economic welfare of agricultural households living around Ruteng Park. This change in welfare is a measure of the value of drought mitigation, which is one of several potential benefits (and costs) of a large forest park such as Ruteng. These services can be related to other conventionally valued market goods and services as either substitutes or complements, because households make production and consumption tradeoffs among market and non-market goods (Mäler, 1991). Thus, by identifying the main production relations and economic tradeoffs, the value of drought mitigation can be estimated as 'willingness to pay (WTP)' that is measured in terms of market products. Section 2 shows that this value can be measured as the incremental profits resulting from the increase in baseflow. Studies that measure the impact of soil erosion, ozone pollution, or wetland quality on agriculture (or mariculture) in terms of marginal cost or profit effects are empirical precedents for the approach used to value drought mitigation services. Apart from valuing distinctly different ecosystem functions, these studies focus on measures of environmental value to producers, rather than to producer-consumer households. ${ }^{4}$

The rest of this paper is structured along the following lines. First, section 2 describes an agricultural household model in detail, using equa-

${ }^{4}$ Two classes of ecosystem services have received the most attention from economists: (a) wetlands services (Lynne, Conroy, and Prochaska, 1981), and (b) ozone pollution (Garcia et al. 1986). In both cases, some proxy for the ecosystem service (e.g., saline concentrations in estuarine wetlands or ozone concentrations in farming counties) is related to a production activity (e.g., shrimp or corn production), typically using econometric methods. The theoretical basis for this approach to value ecosystem services as incremental profits (lowered production costs) is summarized in Freeman and Harrington (1990) and Huang and Smith (1998). Four decades ago, Eckstein (1958) and Ciriacy-Wantrup (1961) proposed a similar reliance on market data and production tradeoffs to evaluate watershed services. In the context of the 'water project derivatives' of the 1960s, they treat a watershed as a 'producing unit' and watershed services as 'producer goods'. 
tions and figures to establish the theoretical basis for drought mitigation values. Section 3 briefly presents the empirical model. Section 4 describes the baseflow simulations, the data collection procedures, the study area, and the variables in the empirical model. The results are presented in section 5. Finally, section 6 discusses methodological and policy implications.

\section{Theory of drought mitigation value: agricultural household model}

A static agricultural household model is developed to show that the value of the drought mitigation service is measured by incremental profits, the money metric of the utility increase. Even though drought mitigation influences household well being through production activities, it is important to develop a comprehensive model that relates drought mitigation, production, profits, and utility of farming households because in neoclassical economics theory, welfare (well being or utility) is characterized within a utility maximization framework.

Agricultural households maximize utility, $U$, which is assumed to be a concave, continuous, twice-differentiable function of agricultural commodities, $X$, (e.g., cereal) and inputs, $Y$ (e.g., leisure). The function is conditioned by household characteristics, $H$. Utility maximization is subject to four constraints. First, an input constraint implies that the sum of 'own' input supply, $R$, and 'own' input consumption, $Y$, cannot exceed the household input endowment, $T$, which depends on household characteristics, $H$. Second, a convex, continuous agricultural production function, $F$, assumes that baseflow, $W$, is a fixed input that measures the background drought environment of the farm. $W$ is a weak complement to other production inputs, $V$, or outputs, $Q$, because the demand for $W$ is zero if there is no agricultural production (Mäler, 1991). Biophysical and socioeconomic inputs, Z, also mediate the production technology. Third, the household's budget constraint ensures that expenditures are equal to the sum of the monetary equivalent of the household input endowment, agricultural profits, $\pi$, and exogenous income, $E$; this sum is the 'Beckerian' full income (Strauss, 1986). Fourth, two additional constraints, collectively termed 'market environment constraints', are imposed to show the role of the market environment in deriving a theoretically correct measure of value. If a perfect market exists for the particular output or input, then the output or input can be freely traded and the market constraint is not binding (the multiplier is zero). The exact nature of the market constraint determines the magnitude of the restriction parameter, $M_{Q}$ and $M_{V}$. Equation (1) describes the utility-maximization problem

$$
\begin{aligned}
& \text { Maximize }_{x, y, q, v, \lambda, \mu} \\
& \begin{aligned}
\mathscr{L} & =U(X, Y ; H)+\lambda\left[p_{v} \cdot T(H)+\left(p_{Q} \cdot Q-p_{v} \cdot V\right)+E-p_{v} \cdot Y-p_{Q} \cdot X\right] \\
& -\psi[F(Q, V ; W, Z)]+\mu_{Q}\left[M_{Q}-Q+X\right]+\mu_{v}\left[M_{v}-V+T(H)-Y\right]
\end{aligned}
\end{aligned}
$$

The first-order conditions for the maximization problem, which have the standard equi-marginal interpretations, are presented in appendix 1. By assumption $U$ and $F$ have the necessary properties to ensure that secondorder conditions for utility maximization hold. The key result is that 
households face virtual prices, which are the set of prices that would induce the household to make the same choices in a perfect market environment as it actually makes when one or more markets are imperfect (Thorton and Eakin, 1992). The virtual price is equal to the sum of the market price and the shadow price and, therefore, deviates from market price by the amount equal to the shadow price depending on whether the market constraint is binding or not.

Because $W$ is a producer good, an increase in baseflow (drought mitigation) increases household welfare, $U$, through the production process, and its value is measured as an increase in profits, $d \pi$, which is equal to the marginal WTP,$d W T P$. This $\mathrm{d} \pi$ is the amount of exogenous income, $d E$, that could be taken away to compensate for the $d \pi$ arising out of higher $W$, holding the household at the initial welfare level. The marginal profit, $d \pi$, thus measures the value to the household of increased $W$. By the envelope theorem, a marginal increase in baseflow, $d W$, increases utility, $d U$, only through the production function, $F$, and as derived in equations (2), dWTP is equal to $d E / d W$ and to $d \pi / d W$ (see appendix 1 for details).

$$
\begin{aligned}
d U & =0 \Rightarrow d W T P=-\frac{d E}{d W}=-\frac{\psi}{\lambda} \cdot F_{W}=[\therefore] \frac{\psi}{\lambda} \cdot F_{Q} \cdot Q_{W}+\frac{\psi}{\lambda} \cdot F_{V} \cdot V_{W} \\
& =\left[p_{Q}-\frac{\mu_{Q}}{\lambda}\right] \cdot Q_{W}-\left[p_{V}+\frac{\mu_{V}}{\lambda}\right] \cdot V_{W}=\frac{\partial \pi^{\text {observed }}}{\partial W}+\frac{\partial \pi^{\text {shadow }}}{\partial w}
\end{aligned}
$$

Significance of shadow profit: testing for separability

The marginal value of drought mitigation is equal to the observed marginal profit plus the marginal 'shadow profit'. This 'shadow profit' arises when the households face virtual prices that deviate from the market prices by the shadow prices due to binding market constraints. When the market constraint is not binding $\left(\mu_{Q}=0=\mu_{V}\right)$, the marginal value of drought mitigation is equal to the marginal observed profit. ${ }^{5} d \pi$ is an appropriate measure of the marginal WTP for drought mitigation as long as the household production and consumption decisions are separable, which occurs when production is independent of consumption even though consumption depends on production (Singh, Squire, and Strauss (eds.), 1986). Under separability, household characteristics, $H$, that influence consumption, do not affect production allocations $Q$ and $V$. Thus, an

\footnotetext{
${ }^{5}$ The empirical implication of a non-zero and unknown shadow price or mismeasured virtual price is that neither the original parameters (and the constraints they are supposed to satisfy) nor the equilibrium level of profit can be identified and, therefore, measurements of profits are problematic. The 'endogenous price' problem has been discussed in the literatures on non-linear hedonic price functions and on estimation of demand for public goods from household production functions, both of which suggest that additional information on the household is necessary to identify structural equations or endogenous prices (Bockstael and McConnell 1983). Jacoby (1993) illustrates the estimation of shadow wages using socio-demographic characteristics of farming households.
} 
empirical test of separability is the statistical significance of $H$ in estimated output supply and input demand functions or in the profit function. Statistical or economic insignificance of $H$ coefficients is tantamount to insignificance of the shadow profit, implying that changes in observed profit are a theoretically correct measure of the value of drought mitigation. Using a similar test, Pitt and Rosenzweig (1986) and Benjamin (1992) present evidence for perfect markets in agrarian communities of Java, Indonesia. Scitovszky (1943) was one of the first to recognize the importance of perfect markets in equating utility-profit-maximizing choices for owner-firms.

\section{Value of drought mitigation}

Given that drought mitigation $(\Delta W)$ is exogenous to the household, integration of the marginal profits over the range from baseline, $W_{0}$, to elevated, $W_{1}$, baseflow generates the incremental profits, $\Delta \pi$, that result from $\Delta W$ (equation (3)). ${ }^{6}$ This is equal to the change in area under the profit curve, or the area bounded by the input demand or output supply curves of a profit-maximizing firm (Freeman and Harrington, 1990).

$$
\Delta \pi=W T P=\int_{W_{0}}^{W_{1}} \pi_{W} d W
$$

Assuming complete markets, incremental profits are a theoretically appropriate measure of incremental value. Figure 1 illustrates this logic using

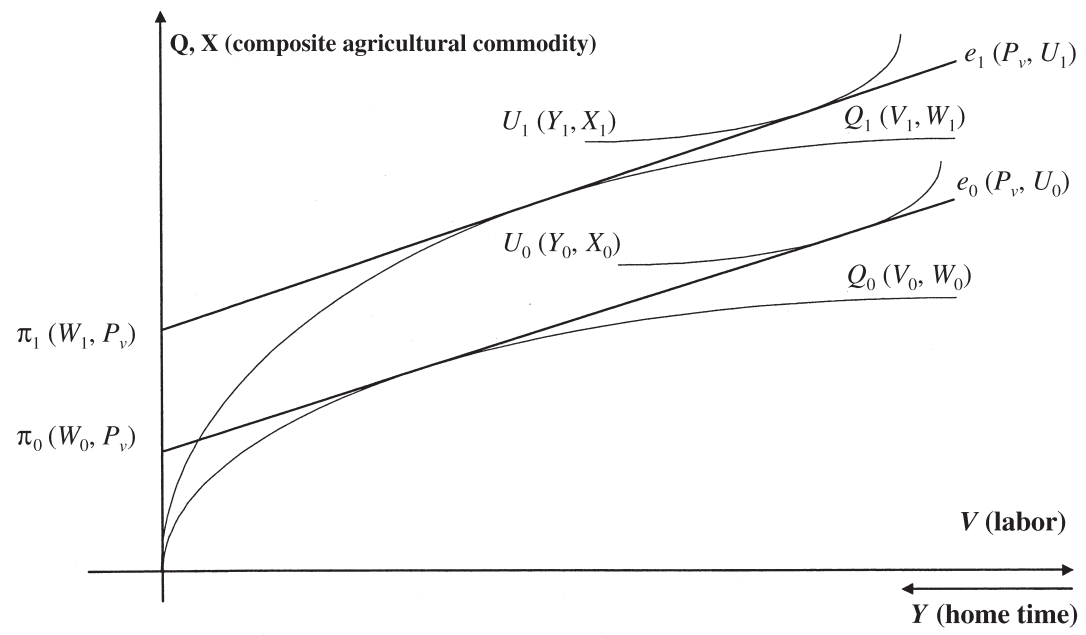

Figure 1. Value of drought mitigation to representative household

Note: $Q$ is the numeraire such that $P_{Q}=1$ and $P_{V}$ and $\pi$ are normalized by $P_{Q}$.

${ }^{6}$ Following the environmental valuation literature that use static models (Huang and Smith, 1998; Freeman and Harrington, 1990), we assume path independence in integrating the marginal value (i.e. line integral of the gradient is path independent) and imply that the welfare measure depends on the difference between 
the case of a typical household based in the affected watersheds, and experiences the baseflow increase $\left(W_{0}\right.$ to $\left.W_{1}\right)$ and the resulting utility increase $\left(U_{1}-U_{0}\right)$. A monetary measure of this increased utility, or the value of drought mitigation, is the expenditure difference, $e_{1}-e_{0}(\Delta e)$. Because $W$ affects utility only through the profit level and markets are perfect, the associated change in profits, $\pi_{1}-\pi_{0}(\Delta \pi)$ is equivalent to $\Delta e$ and, therefore, is an observable money measure of value of $\Delta W .^{7}$

\section{Empirical model of economic value of drought mitigation}

The normalized quadratic, a second-order flexible approximation of the profit function, is used to establish the relationship between baseflow and household agricultural production.

$\pi_{i}=\beta_{0}+\beta_{P n} \cdot P_{n i}+0.5 \cdot \beta_{P n n(j)} \cdot P_{n i}^{2}+\beta_{Z n} \cdot P_{n i} \cdot Z+\beta_{w n} \cdot P_{n i} \cdot W_{0 i}+\epsilon_{1}(4)$ In equation (4), annual household profits, $\pi_{i}$, are estimated as a function of baseflow, $W_{i}$, vector of output and input prices, $P_{n i}$, and a vector of fixed inputs, $Z_{i}$. The subscript, $i$, refers to the household. Note that $W_{i}$ is an index of the hydrological environment of the household. We do not attempt to specify the technology by which households use baseflow; all that this dual specification of the production process assumes is that agricultural production (and, therefore, agricultural profit) is impossible without plant available moisture.

The associated forms of the derived output supply and input demand functions are presented in table $1 \mathrm{~A}$ and $\mathrm{B}$. These equations are derived by taking the first derivative of the quadratic specification with respect to price (Hotelling's Lemma) and this implies cross-equation restrictions on all coefficients, i.e. coefficients on the baseflow-price interaction terms in the profit equation are equal to the coefficients on the baseflow term in the output supply (and input demand) equation. The separability (complete market) assumption can be tested by studying the statistical significance of household compositional variables, $H_{r i}$ in estimated output supply and input demand equations.

\section{Data collection and summary description of study area}

The empirical model is based on two kinds of data: secondary environmental statistics that describe the hydrological situation in the study area and household survey information on the microeconomic profile of the Manggarai.

the final and initial values. In this case, we ask the question 'what is the increase in farming profits if more baseflow were to become available today'. While the dynamic process of the baseflow creation and its use by farmers is an interesting question, our narrower objective and use of a static model and cross-sectional data focus our attention on the overall contribution of baseflow.

${ }^{7}$ A diagramatic expression of perfect markets is the price ratio line, tangent to and separating the production function and the utility curve (or the separating hyperplane). The slope of this line is determined by market forces and not the household allocations. By geometry, $\Delta e$ is equal to $\Delta \pi$ because both are equal to the vertical distance between the two price ratio lines, which remain parallel (complete markets) even though baseflow changes household allocations. 
Table 1. Normalized quadratic technology: profit function, marginal and incremental values

A. Profit function

$$
\pi_{i}=\beta_{0}+\beta_{P n} \cdot P_{n i}+0.5 \cdot \beta_{P n n(j)} \cdot P_{n i}^{2}+\beta_{Z n} \cdot P_{n i} \cdot Z+\beta_{w n} \cdot P_{n i} \cdot W_{0 i} \cdot W_{0 \mathrm{i}}+\epsilon_{1}
$$

B. Output supply (input demand) function

$$
\mathrm{q}_{n i}=\beta_{P n i}+\beta_{P n n} \cdot \mathrm{P}_{n i}+0.5 \cdot \beta_{P n j} \cdot \mathrm{P}_{j i}+\beta_{Z n} \cdot Z+\beta_{w n} \cdot W_{0 i}+\epsilon_{n 2}
$$

C. Value of drought mitigation service

$$
\begin{gathered}
\text { Marginal value } \\
\pi_{w i}=\frac{\partial \pi_{i}}{\partial W_{i}}=\sum_{1}^{n} \hat{\beta}_{w n}{ }^{*} P_{n i} \\
\text { Incremental value } \\
\Delta \pi_{i}=\sum_{1}^{n}\left[\int_{W_{0 i}}^{W_{1 i}}\left(\hat{\beta}_{w n}{ }^{*} P_{n i}\right) d W\right]=\sum_{1}^{n}\left(\hat{\beta}_{w n}{ }^{*} P_{n i}\right)^{*}\left(W_{1 i}-W_{0 i}\right)
\end{gathered}
$$

Hydrological data collection

The hydrological analysis is based on secondary data derived from: (1) hydrological models from the regional soil and water conservation departments that supplied information on evapotranspiration, interception, stormflow, and ground water recharge, (2) precipitation records from the regional meteorological department, and (3) topographic, vegetation, and soils data from the national ministries of public works and agriculture. An Indonesian hydrologist used a water balance model to derive baseflow volumes for thirty seven sub-watersheds $(j)$ in the buffer zone of the park. Process-based hydrological models are used to calculate the evapotranspiration $\left(E t_{j}\right)$, interception $\left(I n_{j}\right)$, stormflow $\left(S f_{j}\right)$, and ground water recharge $\left(G w_{j}\right)$ that correspond to current land use. These calculations are combined with precipitation $\left(P p t_{j}\right)$ records in equation (5) to simulate the annual baseflow volume $\left(W_{j}\right)$, simply referred to as 'baseflow' (see Priyanto (1996) for additional details).

$$
W_{j}=P p t_{j}-\left(E t_{j}+I n_{j}+S f_{j}+G w_{j}\right)
$$

At the hydrological scale in this study, the type of land use and vegetation cover affects all components of the water balance model except for precipitation. For each of the thirty seven sub-watersheds, baseflow levels correspond to the current vegetation cover and, thus, this cross-sectional variation in current baseflow is sufficient to econometrically establish the influence of baseflow on agricultural profits. ${ }^{8}$

${ }^{8}$ There are no projections of the baseflow levels that will result from Ruteng Park's protection and re-establishment of forests. As an alternative to evaluating a hypothetical baseflow change, we conduct exploratory regression of the cross-sectional hydrological data and predict baseflow increases based on regression coefficients. The regression results are reported in appendix 4 . 
Socio-economic data collection

The household data are drawn from a socio-economic survey conducted in the Manggarai district in 1996 as part of a larger project on the economic analysis of protected areas. Details of the larger project and the data collection procedures are presented in Kramer et al. (1997). Because the hydrological effects of the park are likely to dissipate over geographical distance, the study area was restricted to the forty eight village clusters (desas) in the buffer zone of Ruteng Park that are contiguous to the protected area. A map of Indonesia and the study area is presented in figure 2. Ruteng Park is located in the western part of Flores Island in western Indonesia. The study area is presented in figure 3. Of the 13,700 farming households in the buffer zone, five-hundred were chosen on the basis of stratified random sampling in which the weights reflected the population density of the desas. The survey was administered by sixteen Indonesian

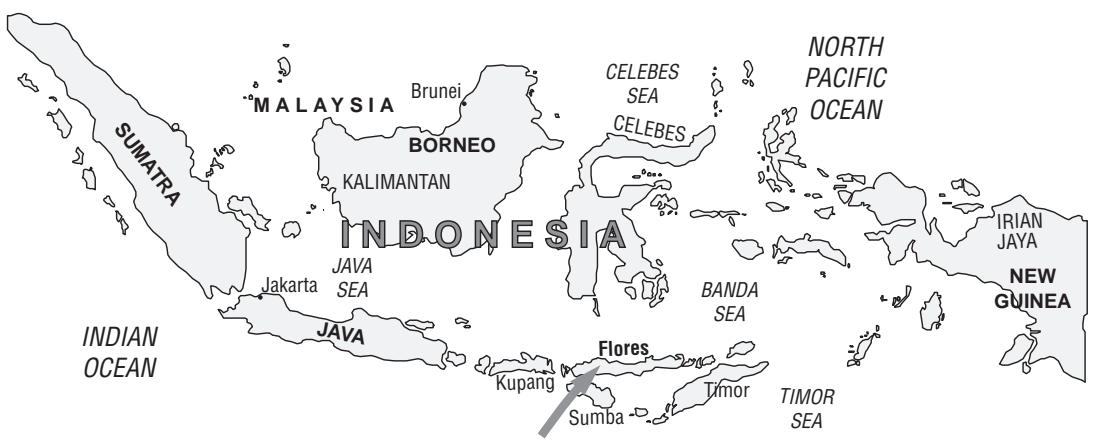

Figure 2. Map of Indonesia (arrow points to Flores Island)

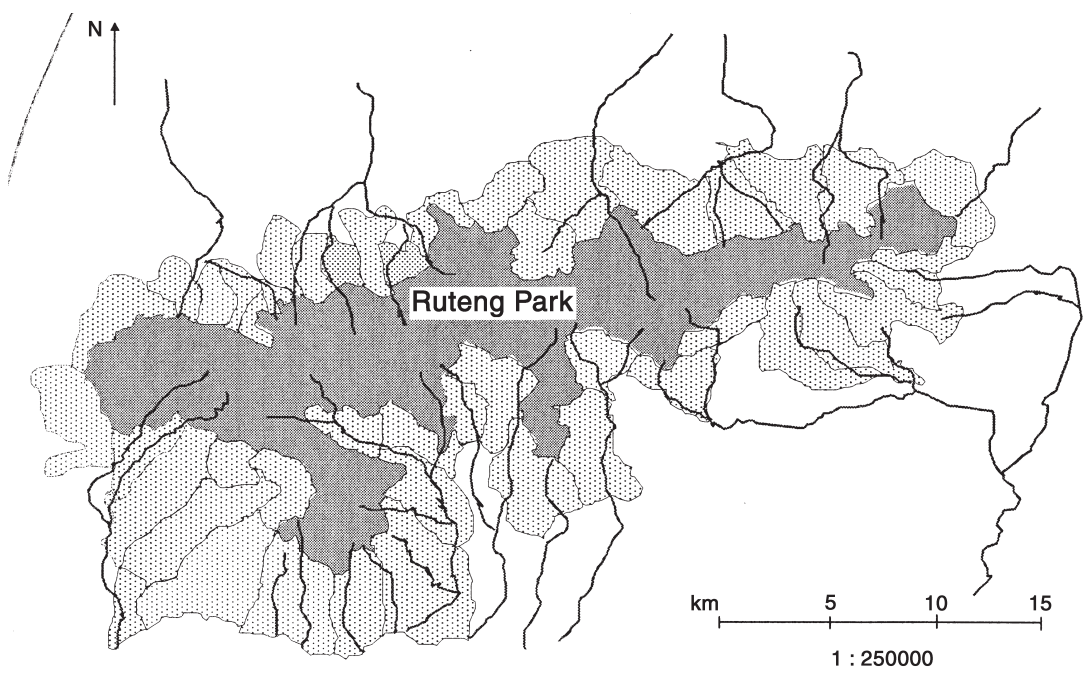

Figure 3. Rivers of Manggarai (37 watersheds in west-central Flores) 
undergraduate agronomy students who spoke the Manggarai dialect. The interviewers received three days of training and were monitored during the data collection. The nineteen page survey was designed using focus groups, pretests, and informant interviews. It comprised of five sections: demographic characteristics, biophysical profile of farm land, farm production budget, labor and financial allocations, and opinions.

\section{Household characteristics}

We report summary statistics in table 2 to describe the buffer zone of Ruteng Park in terms of the typical or average household. The average Manggarai household has little education and wealth. They exhibit a heavy reliance on agriculture, primarily growing coffee and rice, and keeping chickens and pigs. Although 87 per cent of the local people are employed in agriculture, in their own or others farms, non-agricultural sources of employment include local government, NGOs, kiosks, and logging crews. The statistics on both hiring-in and hiring-out labor indicate that the labor markets in Manggarai region are important. ${ }^{9}$ Fertilizers are the other important inputs.

Table 2. Summary description of Ruteng Park buffer zone (Manggarai)

\begin{tabular}{lcc}
\hline Variable & Mean & Std. Dev. \\
\hline Average education of household (years) & 6.00 & 1.89 \\
Average farming experience (years) & 15.1 & 12.4 \\
Illness index (average count) & 1.01 & 0.62 \\
Number of adults & 3.42 & 1.52 \\
Wealth index (number of consumer durables) & 0.82 & 1.28 \\
Electricity (1=available, 0=not available) & 0.14 & 0.35 \\
Expenditure on food (million rupiahs) & 0.31 & 0.41 \\
Annual agricultural profits (million rupiahs) & 0.74 & 1.10 \\
\% of Annual income from agriculture & 85 & 29 \\
Annual production of coffee (kilograms) & 120.5 & 137.2 \\
Annual production of rice (kilograms) & 431.9 & 431.1 \\
Number of pigs owned & 1.7 & 0.9 \\
Number of chickens owned & 5.5 & 4.5 \\
Labor hired out (days) & 56.0 & 91.6 \\
Labor hired in (days) & 21.4 & 14.5 \\
Fertilizer (kilograms) & 38.7 & 54.7 \\
Farm Size (hectares) & 1.27 & 1.1 \\
\% Farm with contour farming & 32 & 38 \\
\% Farm with irrigation & 14 & 25 \\
\% Farm with slope facing north & 23 & 35 \\
\% Farm with volcanic soil & 32 & 39 \\
Steepness of the farm (Likert Scale: 1-4) & 2.25 & 1.00 \\
Annual baseflow (meters) & 1.02 & 0.16 \\
Annual rainfall (meters) & 2.50 & 0.33 \\
\hline Sample size (N) & 494 & \\
\hline
\end{tabular}

${ }^{9}$ Fifty eight per cent of all households sampled reported hiring-out labor, whereas 31 per cent reported hiring-in labor. In all villages sampled at least one household was hiring-out labor, and in 87 per cent of the villages at least one household was hiring-in labor. 
Typically, the Manggarai farm small, steep, and unirrigated parcels of land that has primarily volcanic soil. While the Manggarai region receives on the average 2.5 meters of rainfall annually, the fact that about 40 per cent (1.02 meters) stays in the system as baseflow (a more appropriate drought measure) indicates that many sub-watersheds are likely to frequently experience drought situations, especially during the dry season.

Next we briefly summarize the model specification. For the profit function the dependent variable is annual agricultural profits, $\pi_{i}$, calculated as total revenue less total variable costs. The independent variables are prices, fixed inputs, and variables for the separability test. The set of prices, $P_{n i^{\prime}}$ include two chief outputs - coffee and rice, and one primary inputlabor. Fixed inputs, $Z_{i}$, are grouped into two sets: (1) conventional private quasi-fixed inputs-amount of farm land and extent of private irrigationand (2) bio-physical fixed inputs-baseflow, rainfall, and slope of land (measured on a four-point Likert scale referring to 'flat', 'somewhat steep', 'steep', and 'very steep' land parcels). The five household compositional variables $\left(H_{r i}\right)$, used to test for the completeness of markets, include: family size, fraction of household reporting illness, average age, fraction of household who are adults, and fraction of household who are males. If this set of five variables is statistically unrelated to coffee and rice supply and labor demand, it suggests that production decisions are made independent of consumption decisions because the labor and the food market are perfect and hired labor and purchased food can be substituted for family labor and own production. The fact that a large proportion of households report input and output prices, and the proximity of roads and other market infrastructure (e.g., stores and credit facilities) provides some evidence that markets are complete for agricultural products and labor.

\section{Results}

In table 3, we report the results from estimating the normalized quadratic profit function, as defined in equation (4) and table 1A. In table 4, we present the results of the estimated output supply and input demand functions for the quadratic function (table 1B). First, we summarize the results of our separability tests. Estimated coffee and rice supply and labor demand functions that included five household compositional variables are reported in appendix 3. Of the fifteen coefficients associated with the compositional variables in the three estimated equations, twelve are statistically insignificant and the three statistically significant variables are economically insignificant. ${ }^{10}$ The five variables are jointly insignificant in each equation. These results legitimize the complete market assumption.

${ }^{10}$ Given the possibility that collinearity of the household compositional variables could result in statistical insignificance, the first principal component of the five variables was also tested in separate regressions (Greene, 1997, pp. 424-427). This variable too was statistically insignificant. Our results are robust to the inclusion of other socio-demographic variables, such as education, and to the CobbDouglas specification. A reviewer has suggested that the overall insignificance of these regressors could be due to data quality. While acknowledging this possibility, we believe that lacking better empirical tests and/or potentially better data, the best interpretation of our data is the rejection of the incomplete market hypothesis. 
Table 3. Generalized least square estimates of normalized quadratic profit function

\begin{tabular}{|c|c|c|c|}
\hline \multicolumn{2}{|c|}{ Description of explanatory variable } & \multirow{2}{*}{$\frac{\beta}{-270.21}$} & \multirow{2}{*}{$\frac{P \text {-value }}{0.006}$} \\
\hline$P_{\eta}$ & Coffee price & & \\
\hline & Rice price & -1167.80 & 0.017 \\
\hline & Labor price & -261.72 & 0.000 \\
\hline \multirow{3}{*}{$P_{n}{ }^{2}$} & Coffee price ${ }^{2}$ & 0.27 & 0.89 \\
\hline & Rice price ${ }^{2}$ & 308.26 & 0.003 \\
\hline & Labor price $^{2}$ & 9.56 & 0.001 \\
\hline \multirow{3}{*}{$P_{n}^{*} P_{j}$} & Coffee price ${ }^{*}$ Rice price & -7.47 & 0.70 \\
\hline & Coffee price ${ }^{*}$ Labor price & -2.68 & 0.38 \\
\hline & Rice price ${ }^{*}$ Labor price & -55.45 & 0.007 \\
\hline \multirow{5}{*}{$P_{1}^{* Z}$} & Coffee price ${ }^{*}$ Farm size & 88.11 & 0.000 \\
\hline & Coffee Price * Baseflow & 155.65 & 0.008 \\
\hline & Coffee price ${ }^{*}$ Irrigation & 65.94 & 0.048 \\
\hline & Coffee price $*$ Slope & 7.11 & 0.36 \\
\hline & Coffee price ${ }^{*}$ Rainfall & 56.66 & 0.019 \\
\hline \multirow[t]{5}{*}{$P_{2}^{* Z}$} & Rice price ${ }^{*}$ Farm Size & 411.94 & 0.000 \\
\hline & Rice price ${ }^{*}$ Baseflow & 475.44 & 0.076 \\
\hline & Rice price ${ }^{*}$ Irrigation & 1462.44 & 0.000 \\
\hline & Rice price * Slope & -65.33 & 0.091 \\
\hline & Rice price * Rainfall & 255.77 & 0.046 \\
\hline \multirow[t]{5}{*}{$P_{3}^{*} Z_{P}$} & Labor price ${ }^{*}$ Farm size & -18.70 & 0.000 \\
\hline & Labor price ${ }^{*}$ Baseflow & 3.57 & 0.90 \\
\hline & Labor price ${ }^{*}$ Irrigation & -60.90 & 0.000 \\
\hline & Labor price ${ }^{*}$ Slope & -6.19 & 0.11 \\
\hline & Labor price * Rainfall & 71.22 & 0.000 \\
\hline \multicolumn{2}{|c|}{ Constant } & 130.49 & 0.13 \\
\hline \multicolumn{2}{|c|}{$N$} & 487 & \\
\hline \multicolumn{2}{|c|}{ Adjusted $\mathrm{R}^{2}$} & 0.28 & \\
\hline \multicolumn{2}{|c|}{$\chi^{2}(18)$ statistic ${ }^{*}$} & 134.21 & 0.000 \\
\hline
\end{tabular}

Note: ${ }^{*}$ Cross equation parameter restrictions on all terms. A separate specification with parameter restrictions on price, price squared, and 'price baseflow' terms could not be rejected at a 99 per cent confidence level. Acknowledging an efficiency, versus bias tradeoff, the above table reports only the theoretically correct specification, i.e. restrictions on all parameters, despite the high $\chi^{2}$ statistic.

The normalized quadratic profit, output supply (coffee and rice), and input demand (labor) functions are estimated as a SUR equation system with cross-equation parameter restrictions, e.g. the coefficient on coffee price in the profit equation is equal to the constant in the coffee supply equation (see tables $1 \mathrm{~A}$ and $\mathrm{B}$ for all restrictions). The profit and prices are normalized with respect to the price of fertilizer, and the fertilizer demand equation is dropped to ensure linear independence of the equations. The $\chi^{2}(27)$ statistic of 130 suggests that the cross-equation restrictions should be rejected, but many coefficients in the unrestricted system are statistically insignificant, and have theoretically implausible sizes and signs. ${ }^{11}$

${ }^{11}$ A partially restricted system, a hybrid of the completely restricted and unrestricted system was also estimated. The signs and significance of baseflow coefficients are not substantially different in these two alternative regressions. 
Table 4. Generalized least square estimates of output supply and input demand functions of normalized quadratic profit function

\begin{tabular}{lccc}
\hline & Coffee & Rice & Labor* $^{* *}$ \\
Description of explanatory variable & $\beta(P$-value $)$ & $\beta(P$-value $)$ & $\beta(P$-value $)$ \\
\hline Coffee price (\$/kilogram) & 0.27 & -7.47 & 2.68 \\
& $(0.89)$ & $(0.70)$ & $(0.38)$ \\
Rice price (\$/kilogram) & -7.47 & 308.26 & 55.45 \\
& $(0.70)$ & $(0.003)$ & $(0.007)$ \\
Labor price (\$/day) & -2.68 & -55.45 & -9.56 \\
& $(0.38)$ & $(0.007)$ & $(0.001)$ \\
Farm size (hectares) & 88.11 & 411.94 & 18.70 \\
& $(0.000)$ & $(0.000)$ & $(0.000)$ \\
\% Farm with irrigation $(0-1)$ & 65.94 & 1462.44 & 60.90 \\
& $(0.048)$ & $(0.000)$ & $(0.000)$ \\
Steepness of farm land (0-4) & 7.11 & -65.33 & 6.19 \\
& $(0.36)$ & $(0.091)$ & $(0.11)$ \\
Level of annual rainfall (meters) & 56.66 & 255.77 & -71.22 \\
& $(0.018)$ & $(0.046)$ & $(0.000)$ \\
Level of annual baseflow (meters) & 155.65 & 475.45 & -3.60 \\
& $(0.008)$ & $(0.076)$ & $(0.90)$ \\
Constant & -155.43 & -1167.80 & 261.72 \\
& $(0.29)$ & $(0.017)$ & $(0.000)$ \\
\hline Adjusted ${ }^{2}$ & 0.12 & 0.15 & 0.17 \\
Sample size & 487 & & \\
Restrictions statistic*: $\chi^{2}(27)$ & 134.21 & & \\
& $(0.000)$ & & \\
\hline Notes: & & &
\end{tabular}

Notes: * Cross equation parameter restrictions on all terms. Only the theoretically correct specification, i.e. restrictions on all parameters, is reported here, despite the high $\chi^{2}$ value (see text for explanation).

** The coefficients in the labor equation are the negative of coefficients of corresponding variables in the profit equation.

The discussion here is limited to the theoretically correct restricted system, acknowledging that the exclusive attention to these coefficients accepts some bias in the interest of greater efficiency. The 'goodness of fit' is measured by Adj. $R^{2}(0.28,0.12,0.15$, and 0.17 for the profit, coffee, rice and labor functions respectively). Because the variables in the supply and demand equations have the same coefficients and therefore the same interpretation as the corresponding variables in the profit equation (compare corresponding equations in tables $1 \mathrm{~A}$ and $\mathrm{B}$ and the variables in tables 3 and 4), the coffee, rice, and labor equations are used to evaluate the theoretical strength of the model.

The own price coefficients in the coffee, rice, and labor equations show

The $\chi^{2}$ statistic indicates that restrictions cannot be rejected at a 99 per cent significance level, and the model has theoretically appropriate regression coefficients. There are no significant differences in estimated incremental values and profit elasticities between the unrestricted, partially restricted, and completely restricted systems of equations. 
that profits are increasing in output prices and decreasing in input prices (although the coffee coefficient is insignificant). The cross-price elasticity with respect to labor in both the coffee and rice equations also has the expected negative sign. Coefficients on farm size and irrigation show that profits are positively related to farm size, and understandably irrigation has a greater effect on the water-intensive output, rice. ${ }^{12}$ Steep slopes are negatively correlated with rice supply, and rainfall increases output supply while diminishing labor demand.

\section{Estimated marginal value of baseflow}

Critically, the baseflow variable has a positive and significant coefficient in both the coffee and rice supply equations, lending support to the central hypothesis that drought mitigation services can make positive contributions to agricultural profits, in this case through increased production of the chief crops, coffee and rice. Based on the formula in table $1 \mathrm{C}$ and the coefficients in table 4 the estimated elasticity of profit with respect to baseflow is 1.29 for the 'typical household', characterized by the sample mean value of all regressors in the statistical model. The mean marginal annual profit is $\$ 0.36$ per mm of baseflow. Median, minimum, and maximum marginal profits in nine Manggarai counties (kecamatan) are reported in table 5 to describe the spatial distribution of economic benefits. These estimated values provide a credible approximation of the economic contribution of baseflow (an indicator of drought mitigation) to agricultural profitability in Manggarai. This claim rests on the values derived from estimated profit parameters that are economically meaningful and statistically significant.

Table 5. Marginal value of baseflow for Manggarai counties

\begin{tabular}{|c|c|c|c|c|c|}
\hline \multirow{2}{*}{$\begin{array}{l}\text { Kecamatan } \\
\text { (county) }\end{array}$} & \multirow{2}{*}{$\begin{array}{l}\text { Number of } \\
\text { households } \\
\text { sampled }\end{array}$} & \multicolumn{2}{|c|}{ Baseflow (mm) } & \multicolumn{2}{|c|}{ Marginal value (\$/mm } \\
\hline & & median $^{*}$ & $\min / \max *$ & median* & $\min / \max ^{*}$ \\
\hline Borong & 83 & 1,071 & $958 / 1,186$ & 0.35 & $0.27 / 0.44$ \\
\hline Elar & 64 & 1,075 & $923 / 1,082$ & 0.37 & $0.27 / 0.51$ \\
\hline Langke Rembong & 38 & 904 & $841 / 904$ & 0.37 & $0.28 / 0.50$ \\
\hline Pembantu Borong & 29 & 870 & $864 / 923$ & 0.37 & $0.28 / 0.46$ \\
\hline Pembantu Elar & 29 & 1,043 & $1,043 / 1,109$ & 0.35 & $0.28 / 0.42$ \\
\hline Pembantu Lambaleda & 127 & 1,144 & $904 / 1350$ & 0.35 & $0.27 / 0.46$ \\
\hline Pembantu Ruteng & 23 & 904 & $904 / 904$ & 0.34 & $0.27 / 0.50$ \\
\hline Ruteng & 22 & 848 & $793 / 904$ & 0.40 & $0.31 / 0.42$ \\
\hline Satarmese & 72 & 816 & $770 / 1,044$ & 0.35 & $0.27 / 0.46$ \\
\hline
\end{tabular}

Notes: * Median, minimum, and maximum for the set of sampled households within the county.

** These benefits are per household per year (measured at three different points of the distribution-median, minimum and maximum).

12 The irrigation effect is somewhat diminished for rice production in watersheds with higher baseflow, as indicated by the coefficient on interaction terms of baseflow and irrigation. In the interest of analytical tractability, we did not pursue these 'third-order effects' any further. 
Incremental value of drought mitigation: an exploratory simulation

We do not have projections of the baseflow levels that will result from Ruteng Park's protection and re-establishment of forests. As an alternative to evaluating a hypothetical baseflow change, we construct an exploratory model, predict baseflow by analyzing the cross-sectional hydrological data, and report results in appendix $4 .{ }^{13}$ A regression of baseflow as a percentage of rainfall on forest cover, rainfall, slope, and percentage of primary forest cover (in quadratic terms), has an Adj. $\mathrm{R}^{2}$ of 0.72 . The coefficient on the forest cover variable is positive and significant, offering further evidence of the link between forests and drought mitigation. Simulated baseflow, calculated at 25 and 75 per cent increases in forest cover (bounded above by 100 per cent), are reported in table 6A and B

Table 6. Drought mitigation benefits of increased forestation (25\% and $75 \%$ ) in Manggarai counties

\begin{tabular}{|c|c|c|c|c|}
\hline \multirow{2}{*}{$\begin{array}{l}\text { Kecamatan } \\
\text { (county) } \\
6 A\end{array}$} & \multicolumn{2}{|c|}{$\begin{array}{l}\text { Baseflow increase } \\
\text { from } 25 \% \text { increase in } \\
\text { forest cover }(\mathrm{mm})\end{array}$} & \multicolumn{2}{|c|}{$\begin{array}{l}\text { Drought mitigation } \\
\text { benefits of } 25 \% \text { forest } \\
\text { cover increase }^{*}(\$)^{* *}\end{array}$} \\
\hline & median & $\min / \max$ & median & $\min / \max$ \\
\hline Borong & 15 & $-25 / 49$ & 4.27 & $-10.67 / 20.45$ \\
\hline Elar & -17 & $-25 / 14$ & -6.74 & $-12.76 / 4.73$ \\
\hline Langke Rembong & -25 & $-27 / 12$ & -9.57 & $-12.72 / 3.42$ \\
\hline Pembantu Borong & 9 & $-25 / 48$ & 3.36 & $-9.74 / 19.54$ \\
\hline Pembantu Elar & 36 & $12 / 36$ & 10.15 & $3.31 / 15.28$ \\
\hline Pembantu Lambaleda & -23 & $-34 /-4$ & -8.06 & $-14.15 /-1.32$ \\
\hline Pembantu Ruteng & -12 & $-12 /-12$ & -4.25 & $-6.23 /-3.38$ \\
\hline Ruteng & -5 & $-25 / 16$ & -0.86 & $-10.46 / 6.37$ \\
\hline Satarmese & 9 & $-26 / 23$ & 3.35 & $-11.52 / 10.12$ \\
\hline \multirow{2}{*}{$\begin{array}{l}\text { Kecamatan } \\
\text { (county) } \\
\mathbf{6 B}\end{array}$} & \multicolumn{2}{|c|}{$\begin{array}{l}\text { Baseflow increase } \\
\text { from } 75 \% \text { increase in } \\
\text { forest cover* }(\mathrm{mm})\end{array}$} & \multicolumn{2}{|c|}{$\begin{array}{l}\text { Drought mitigation } \\
\text { benefits of } 25 \% \text { forest } \\
\text { cover increase }(\$)^{* *}\end{array}$} \\
\hline & median & $\min / \max$ & median & $\min / \max$ \\
\hline Borong & 25 & $-31 / 88$ & 8.48 & $-13.04 / 37.04$ \\
\hline Elar & -24 & $-54 / 21$ & -9.83 & $-24.34 / 9.01$ \\
\hline Langke Rembong & -68 & $-68 / 25$ & -24.68 & $-34.31 / 7.08$ \\
\hline Pembantu Borong & -10 & $-48 / 48$ & -3.32 & $-18.59 / 19.54$ \\
\hline Pembantu Elar & 36 & $12 / 36$ & 10.15 & $3.31 / 15.28$ \\
\hline Pembantu Lambaleda & -66 & $-90 / 28$ & -22.83 & $-37.60 / 11.53$ \\
\hline Pembantu Ruteng & 28 & $28 / 28$ & 9.44 & $7.52 / 13.84$ \\
\hline Ruteng & -26 & $-69 / 16$ & -7.46 & $-28.21 / 6.37$ \\
\hline Satarmese & 16 & $-24 / 23$ & 4.98 & $-9.11 / 10.12$ \\
\hline
\end{tabular}

Notes: * The minimum of $25 \%$ (75\%) increase or $100 \%$ of watershed area.

${ }^{* *}$ These benefits are per household per year (measured at three different points of the distribution-median, minimum and maximum).

${ }^{13}$ We would like to emphasize that these regressions are an example of exploratory data analysis (EDA). We are using baseflow data generated by the hydrologist and basic knowledge of watershed hydrology to estimate a regression model with the highest predictive power. 
(columns 1 and 2). These simulated increases in forest cover are consistent with the reforestation goals of the Park management. The decreases in baseflow in some watersheds, despite the positive coefficient of the forest cover variable, can be attributed to the negative effect of the percent forest cover variable (the coefficients on the first and second quadratic terms are negative and positive respectively). As discussed in section 1, several biophysical factors condition this relationship; baseflow decreases even as forest cover increases, probably because of the mixed influences of forest conditions, topography, climate, and land use peculiar to those watersheds.

Using the formula in table $1 C$, the simulated baseflow changes can be combined with the marginal value of baseflow (estimated in the profit model) to calculate the incremental value of drought mitigation services. These are reported per household per year in table $6 \mathrm{~A}$ and $\mathrm{B}$ in columns 3 and 4; the reported median, maximum, and minimum amounts are for nine counties. The distribution of incremental values across counties offers three insights. First, increased forest cover will not necessarily increase baseflow (mitigate drought conditions) for all households in a watershed or in all watersheds. Second, there is a distinct spatial pattern to the drought mitigation because the wetter southern watersheds (in Pembantu Borong, Borong, and Satarmese counties), frequently exposed to moist winds from the southern seas and continually shrouded by cloud cover (Binnies and Partners, 1994), consistently realize positive drought mitigation from increases in forest cover. Perhaps in these more moist watersheds, trees are less competitive with agricultural crops. Finally, where increased watershed protection mitigates droughts, the economic benefits can be sizeable (as much as 10 per cent of annual agricultural profits), even though the physical increase in baseflow is small. In sum, to the extent that our exploratory baseflow model is correct, the spatial distribution and economic magnitude of drought mitigation services offer a clear policy message regarding the best locations and importance of public watershed management activities. It is important to emphasize that regardless of the mechanism that generates baseflow, baseflow itself has a positive economic value.

\section{Discussion of methods and policy}

This study shows that hydrological modeling can be combined with applied microeconomic theory and econometric techniques to value a complex ecosystem service: drought mitigation provided by forested watersheds in an agrarian region of a developing country. The multidimensional hydrological service is made analytically tractable by approximating it as a change in baseflow, an index simulated with a waterbalance model. By exploiting the spatial variation in current baseflow, the value of the drought mitigation service can be measured as the marginal profit accruing to agricultural households in the affected watersheds. We derive the theoretical conditions under which changes in profits are an appropriate measure of the value of environmental services received by agricultural households; the requirement is that all relevant markets are complete. 
We estimate a system of equations including functions of agricultural profit, output supply, and input demand to exploit all of the available information. A second-order approximation of the profit function, the normalized quadratic specification, satisfies most theoretical conditions. Market prices and environmental variables are the most important regressors in the estimated model, and the statistical test for the critical structural assumption regarding complete markets is satisfied. For the typical household, the estimated marginal profit and profit elasticities are positive, validating the central hypothesis that baseflow makes positive contributions to agricultural profits and hence welfare of agricultural households ceteris paribus.

Exploratory regression analysis to evaluate the impact of increased forest cover shows that physiographic and climatic factors strongly influence the likelihood of drought mitigation from watershed protection activities. The estimated regressions predict that positive increases in baseflow will arise in the southern watersheds in Pembantu Borong, Borong, and Satarmese counties. While the physical increases in baseflow are small, economic values reported in table 6 that range from 1 to 10 per cent (\$3.5-\$35) of annual agricultural profits indicate the potential for sizeable economic benefits in these watersheds. Based on small and negative correlation coefficients, we also find weak evidence that the estimated values are inversely correlated with agricultural profits and wealth indices. ${ }^{14}$

The estimates of a profit elasticity of 1.29 and a marginal value of $\$ 0.36$ reveal that watershed management that effectively mitigates drought could increase the annual agricultural profit of each household. However, increased watershed protection will mitigate droughts by increasing baseflow only when the watershed has a particular mix of climatic and physiographic features. Therefore, policy makers should adopt a selective approach targeting specific watersheds (with the above characteristics and low protection costs) to fulfill the goals of the management plans to 'provide conservation benefits to communities in the buffer zone' through watershed protection (Indonesian Ministry of Forestry, 1995, vol. I, p. 4). Given that the baseflow prediction module of our study is an exploratory attempt to model bio-physical features, a more rigorous forest hydrological analysis is necessary to identify the precise bio-physical factors that condition the relationship between watershed protection and baseflow. Regardless of the mechanism that effectively mitigates drought, it is clear, however, that increases in baseflow have positive economic value.

While it is not our purpose to conduct a comprehensive cost-benefit analysis, the estimates of annual minimum benefits (\$3.5-\$35) reported above can be compared with watershed re-greening costs, computed as an

${ }^{14}$ We thank a reviewer for encouraging us to investigate whether poor households benefit more than rich ones. Although we find weak negative correlation between estimated values and income and wealth, further proof lies in the existence of 'second-order correlations' between estimated values and wealth. Rigorous investigation of this would require that we incorporate second-order wealth and profit terms in the profit equation and that we abandon the traditional normalized quadratic specification adopted here. 
average annual amount of $\$ 5-\$ 13$ per household. ${ }^{15}$ This type of cost-benefit comparison could help policy makers to judge the overall worthiness of investments in Ruteng Park. To the extent that the hydrological service extends further downstream to counties not included in this study, the results reported above understate the overall worth of drought mitigation service on Flores Island. The Park management could also use the results to explain the economic value of forest protection to local government and communities. Finally, we reiterate that any aggregate value of drought mitigation constitutes one element in the calculation of the net present value of the overall integrated conservation and development project for Ruteng Park.

Our approach to link 'upstream' resource management to 'downstream' economic impacts can be applied to a variety of dispersed or offsite externalities related to natural resources. ${ }^{16}$ Examples of downstream externalities of land and forest management include fisheries, mariculture, hydropower production, navigation, and irrigation that are linked through the water and soil resources. Hodgson and Dixon (1992) and Swallow (1994) illustrate applications to coastal fishing and coral resources. Irrespective of the application, the generalizability of this approach depends critically on the ability to link the non-market upstream resource to a downstream market good.

Although parks in tropical countries have been envisioned as integrated conservation and development projects for more than a decade, few studies have attempted to quantify how conservation of tropical forests facilitates economic development. This study describes and implements a theoretically consistent approach to valuation of drought mitigation services provided by forest protection. Estimated positive value of drought mitigation provides rare evidence of a substantive, quantified economic benefit of tropical forest conservation, and makes an important addition to the literature. Conventional producer welfare theory is applied to the problem of valuing drought mitigation. The theoretical section of the paper shows that this atypical focus on producer (not consumer) surplus measures is an appropriate approach as long as markets for commodities related to the environmental services are complete. We do not be claim that this exercise has established the precise value of a complex ecosystem service. Instead, the estimated economic models and the parameters provide some signals for policy makers and management information to Ruteng Park managers regarding the spatial distribution and economic magnitude of watershed protection benefits. They also provide support for the hypothesis, put forward by hydrological science and the Indonesian

15 This number is computed by multiplying Binnies and Partner's (1994) annual per hectare re-greening cost estimates with the planned hectares of reforestation, and dividing the product by the number of households in the study area. These average costs do not reflect any differences attributed to terrain and pre-existing forest conditions. Thus, we consider such cost-benefit comparisons to be illustrative.

${ }^{16}$ We thank a reviewer for noting the general applicability of the our approach. Gregersen et al. (1987) and Brooks et al. (1992) provide more details on downstream benefits of land use practices. 
government, that protected watersheds can supply latent and unrecognized ecosystem services to local people.

\section{References}

Barbier, E. (1994), 'Valuing environmental functions: tropical wetlands', Land Economics 70(2): 155-173.

Barrett, S. (1997), 'Microeconomic responses to macroeconomic reforms: the optimal soil conservation and the reform of agricultural pricing policies', in P. Dasgupta and K. Goran-Mäler (eds.), The Environment and Emerging Development Issues, vol. II, Oxford: Clarendon Press.

Benjamin, D. (1992), 'Household composition, labor markets, and labor demand: testing for separation in agricultural household models', Econometrica, 60: 287-322.

Binnies and Partners (1994), Master Plan Report: Integrated Water Resources in Flores Island, Indonesia, vol. II, Directorate General of Water Resources Development, Ministry of Public Works, Indonesia.

Bockstael, N. and K. McConnell (1983), 'Welfare measurement in the household production framework', American Economic Review, 73: 806-814.

Bonnell, M. and J. Balek (1993), 'Recent scientific developments and research needs in hydrological processes of the humid tropics', in M. Bonnell, M. Hufschmidt, and J. Gladwell (eds.), Hydrology and Water Management in the Humid Tropics, UNESCO/Cambridge University Press.

Brooks, K., H. Gregersen, P. Ffolliot, and K. Tejwani (1992), 'Watershed management: a key to substainability', in N. Sharma (ed.), Managing the Worlds Forests, Iowa: Kendall/Hunt.

Bruijnzeel, L.A. (1990), Hydrology of Moist Tropical Forests and Effects of Conversion: A State of Knowledge Review, Netherlands: IAHS.

Ciriacy-Wantrup, S. (1961), 'Philosophy and objectives of watershed policy', in G. Tolley and F. Riggs (eds.), Economics of Watershed Planning, Ames, Iowa: Iowa University Press.

Dasgupta, P. (1996), 'The economics of the environment', Environment and Development Economics, 1(4): 387-428.

Dixon, J. (1997), 'Analysis and management of watersheds', in P. Dasgupta and K. Goran-Mäler (eds.), The Environment and Emerging Development Issues, vol. I, Oxford: Clarendon Press.

Eckstein, O. (1958), Water Resource Development: The Economics of Project Evaluation, Cambridge, MA: Harvard University Press.

FAO (1997), 'State of world's forests', Food and Agricultural Organization, Rome.

Freeman, A. (1996), 'On valuing the services and functions of ecosystems', in R. Simpson and N. Christensen (eds.), Human Activity and Ecosystem Function: Reconciling Economics and Ecology, Chapman \& Hall.

Freeman, A. and W. Harrington (1990), 'Measuring the welfare values of productivity changes', Southern Economics Journal, 56(4): 892-904.

Garcia, P., B. Dixon, J. Mjelde, and R. Adams (1986), 'Measuring the benefits of environmental changes using duality approach: the case of ozone and Illinois cash gains farms', Journal of Environmental Economics and Management, 13(1): 69-80.

Georgiou, S., D. Whittington, D. Pearce, and D. Moran (1997), Economic Values and the Environment in the Developing World, Cheltenham: Edward Elgar.

Greene, W.H. (1997), Econometric Analysis. Third Edition. Prentice Hall, New Jersey. Gregersen, H., K. Brooks, J. Dixon, and L. Hamilton (1987), Guidelines for Economic Appraisal of Watershed Management Projects, FAO Conservation Guide No. 16, Rome. 
Hodgson, G. and J. Dixon (1992), 'Sediment damage to marine resources: environment and economic analysis', in J. Marsh (ed.), Resources and Environment in Asia's Marine Sector, New York: Taylor and Francis, pp. 421-445.

Horowitz, J. (1998), 'Review of "The Environment and Emerging Development Issues", vols. I and II, edited by P. Dasgupta and K-G. Maler, UNU/WIDER, 1997', Journal of Environmental Literature, 36(3): 1529-1530.

Huang, J. and V.K. Smith (1998), 'Weak complementarity and production', Economic Letters 60: 329-333.

Indonesian Ministry of Forestry (1995), Integrated Conservation Management Plan for Ruteng Nature Recreation Park: 1995-2020, vols. I and II, Directorate General of Forest Protection and Nature Conservation, Jakarta.

Interagency Partnership on Forests (1997), Implementation Plan of the Intra-agency Task Force on Forests, United Nations Department for Policy Coordination and Sustainable Development.

Jacoby, H. (1993), 'Shadow wages and peasant family labour supply: an econometric application to the Peruvian Sierra', Review of Economic Studies, 60: 903-921.

Kramer, R., S. Pattanayak, E. Sills, and S. Simanjuntak (1997), 'The economics of the Siberut and Ruteng protected areas', Final Report submitted to the Directorate General of Forest Protection and Nature Conservation, Ministry of Forestry, Republic of Indonesia. Nicholas School of the Environment, Durham.

Lynne, G., P. Conroy, and F. Prochaska (1981), 'Economic valuation of marsh areas for marine production processes', Journal of Environmental Economics and Management, 8: 175-186.

Mäler, K-G. (1991), 'The production function approach in developing countries', in J. Vincent, E. Crawford, and J. Hoehn (eds.), 'Valuing Environmental Benefits in Developing Economies', Seminar Proceedings, Michigan State University Graduate Specialization in Resource Economics, East Lansing, Michigan.

Panayotou, T. (1992), 'The economics of environmental degradation: problems, causes and responses', in A. Markandya and J. Richardson (eds.), Environmental Economics: A Reader, New York: St. Martin's Press.

Pitt, M. and M. Rosenzweig (1986), 'Agricultural prices, food consumption, and the health and productivity of Indonesian farmers', in I. Singh, L. Squire, and J. Strauss (eds.), Agricultural Household Models: Extensions, Applications, and Policy, A World Bank Publication, Baltimore: Johns Hopkins University Press.

Priyanto, A. (1996), 'Hydrology specialist report on Ruteng', Directorate General of Forest Protection and Nature Conservation, Ministry of Forestry, Jakarta, Indonesia.

Scitovoszky, T. (1943), 'A note on profit maximization and its implications', Review of Economic Studies, Volume XV: 57-60.

Singh, I., L. Squire, and J. Strauss (eds.) (1986), Agricultural Household Models: Extensions, Applications and Policy, Johns Hopkins Press for the World Bank.

Strauss, J. (1986), 'The theory and comparative statics of agricultural household models: a general approach', in I. Singh, L. Squire, and J. Strauss (eds.), Agricultural Household Models: Extensions, Applications and Policy, Johns Hopkins Press for the World Bank.

Swallow, S. (1994), 'Renewable and nonrenewable resource theory applied to coastal agriculture, forest, wetland and fishery linkages', Marine Resource Economics, 9: 291-310.

Swiss Intercooperation (1996), 'Performance of springs in Manggarai: summary of study by PDAM Ruteng', Ruteng, Flores.

Thorton, J. and K. Eakin (1992), 'Virtual prices and a general theory of the owner operated firms', Southern Economic Journal, April: 1015-1029. 


\section{Appendix 1: The optimization problem}

Maximize $_{X, Y, Q}, \mathrm{~V}, \lambda, \mu$

$$
\begin{gathered}
\mathscr{L}=U(X, Y ; H)+\lambda\left[p_{v} \cdot T(H)+\left(p_{Q} \cdot Q-p_{v} \cdot V\right)+E-p_{v} \cdot Y-p_{Q} \cdot X\right] \\
-\psi[F(Q, V ; W, Z)]+\mu_{Q}\left[M_{Q}-Q+X\right]+\mu_{v}\left[M_{v}-V+T(H)-Y\right]
\end{gathered}
$$

The first-order conditions for the maximization problem are

$$
\begin{array}{ll}
\text { 1. } & U_{X}=\lambda \cdot p_{Q}-\mu_{Q} \\
\text { 2. } & U_{Y}=\lambda \cdot p_{V}+\mu_{V} \\
\text { 3. } & p_{V} \cdot T(H)+\left(p_{Q} \cdot Q-p_{v} \cdot V\right)+E=p_{V} \cdot Y+p_{Q} \cdot X \\
\text { 4. } & \frac{\psi}{\lambda} \cdot F_{Q}=p_{Q}-\frac{\mu_{Q}}{\lambda} \\
\text { 5. } & \frac{\psi}{\lambda} \cdot F_{V}=-p_{V}-\frac{\mu_{V}}{\lambda} \\
\text { 6. } & F(Q, V ; W, Z)=0 \\
\text { 7. } & M_{Q}=Q-X \\
\text { 8. } & M_{V}=V-T(H)+Y
\end{array}
$$

Derivation of $d W T P=d \pi$ is as follows. Holding utility constant $(d U=0)$, and totally differentiating the Lagrangian only with respect to $E$ and $W$, i.e., allowing only $d E$ to compensate for $d W$, we see that the $d W T P$ is equal to $d E / d W$ (equation (3)) and $d \pi / d W$ (equations (3) through (5))

$$
\begin{gathered}
d U=0 \Rightarrow \lambda \cdot d E-\psi \cdot F_{W} \cdot d W=0 \\
\Rightarrow W T P=-\frac{d E}{d W}=-\frac{\psi}{\lambda} \cdot F_{W}
\end{gathered}
$$

Holding $d Z=0$, the total differentiation of the production function (condition 6 in equation (2)), provides an expression for $F_{W}$

$$
F_{W}=-F_{Q} \cdot Q_{W}-F_{V} \cdot V_{W}
$$

Substitution into equation (3) generates equation (5)

$$
\therefore W T P=\frac{\psi}{\lambda} \cdot F_{Q} \cdot Q_{W}+\frac{\psi}{\lambda} \cdot F_{V} \cdot V_{W}
$$

Using the definitions for virtual price derived in conditions 4 and 5 of equation (1), we get

$$
\begin{gathered}
W T P=\left[p_{Q}-\frac{\mu_{Q}}{\lambda}\right] \cdot Q_{W}-\left[p_{V}+\frac{\mu_{V}}{\lambda}\right] \cdot V_{W} \\
=\left[p_{Q} \cdot Q_{W}-p_{V} \cdot V_{W}\right]+\left[-\frac{\mu_{Q}}{\lambda} \cdot Q_{W}-\frac{\mu_{V}}{\lambda} \cdot V_{W}\right]
\end{gathered}
$$




$$
=\frac{\partial \pi^{\text {observed }}}{\partial W}+\frac{\partial \pi^{\text {shadow }}}{\partial W}
$$

\section{Appendix 2: Derivation of the separability test}

Because virtual prices, $P^{*}$, equilibrate the supply and demand sectors of the household such that $V^{*}=M_{V}+T(H)-Y^{*}(., H), P_{V}^{*}$ is a function of household characteristics, $H$, by virtue of being the sum of the exogenous market price and the 'endogenous' shadow price, which is a function, $g(H,$.$) .$

$$
\begin{aligned}
p_{V}^{*} & =p_{V}+\frac{\mu_{V}}{\lambda}=-\frac{\psi_{V}}{\lambda} \cdot F_{V}(Q, V ; W, Z) \\
& =-\frac{\psi}{\lambda} \cdot F_{V}\left[Q, M_{V}+T(H)-Y\left(p_{V^{\prime}} p_{Q^{\prime}} H, W, Z\right) ; W, Z\right] \\
& =p^{*}\left(p_{V^{\prime}} p_{Q^{\prime}} H, W, Z\right)=p_{V}+g\left(H, p_{Q^{\prime}} W, Z\right)
\end{aligned}
$$

By similar logic

$$
p_{Q}^{*}=p_{Q}+h\left(H, p_{Q^{\prime}} W, Z\right)
$$

Shadow prices, $g(H,$.$) and h\left(H_{, .}\right)$, imply that profits, output supply, and input demand will be a function of $H$, a set of 'consumption side' characteristics that would not belong typically in the argument of a neoclassical profit function if allocations were separable and markets were perfect.

$$
\begin{aligned}
\pi & =\pi\left(p_{V}+g(H, .), p_{Q}+h(H, .), W, Z\right) \neq \pi\left(p_{V^{\prime}} p_{Q^{\prime}}, W, Z, H\right) \\
Q & =Q\left(p_{V}+g(H, .), p_{Q}+h(H, .), W, Z\right) \neq Q\left(p_{V^{\prime}} p_{Q^{\prime}} W, Z, H\right) \\
V & =V\left(p_{V}+g(H, .), p_{Q}+h(H, .), W, Z\right) \neq V\left(p_{V^{\prime}} p_{Q^{\prime}}, W, Z, H\right) \\
& \Rightarrow \pi_{H} \neq 0, Q_{H} \neq 0 \text { and } V_{H} \neq 0 \\
& \because p_{V}^{*} \neq 0 \text { and } p_{Q}^{*}{ }^{*} \neq 0
\end{aligned}
$$


Appendix 3: Testing for separability: coffee and rice supply and labor demand with household compositional variables

\begin{tabular}{lccc}
\hline & Coffee & Rice & Labor \\
& Mean $=155$ & Mean $=588$ & Mean $=112$ \\
& $\beta(P$-value $)$ & $\beta($ P-value $)$ & $\beta$ (P-value) \\
Description of explanatory variable & -1.11 & -25.49 & 0.41 \\
Coffee price (\$/kilogram) & $(0.79)$ & $(0.14)$ & $(0.81)$ \\
& 106.49 & 550.45 & 70.75 \\
Rice price (\$/kilogram) & $(0.07$ & $(0.02)$ & $(0.00)$ \\
Labor price (\$/day) & 1.52 & 95.33 & -14.64 \\
& $(0.92)$ & $(0.14)$ & $(0.02)$ \\
Farm size (hectares) & 79.76 & 279.04 & 15.17 \\
& $(0.00)$ & $(0.00)$ & $(0.00)$ \\
\% Farm with irrigation (0-1) & -12.73 & 1078.30 & 54.06 \\
& $(0.77)$ & $(0.00)$ & $(0.00)$ \\
Steepness of farm land (0-4) & 4.91 & -80.80 & 4.92 \\
& $(0.63)$ & $(0.05)$ & $(0.22)$ \\
Level of annual rainfall (meters) & -6.49 & 40.66 & -97.96 \\
& $(0.87)$ & $(0.81)$ & $(0.00)$ \\
Level of annual baseflow (meters) & 173.89 & 578.88 & 4.92 \\
& $(0.02)$ & $(0.05)$ & $(0.22)$ \\
Family size & -5.62 & 12.40 & 089 \\
& $(0.40)$ & $(0.66)$ & $(0.74)$ \\
Fraction of family reporting illness & -58.31 & 126.64 & -22.33 \\
& $(0.01)$ & $(0.19)$ & $(0.02)$ \\
Average age of family & -0.72 & 16.05 & 0.11 \\
& $(0.65)$ & $(0.02)$ & $(0.86)$ \\
Fraction of family who are males & -29.30 & 250.16 & -17.07 \\
& $(0.66)$ & $(0.37)$ & $(0.52)$ \\
Fraction of family who are adults & 127.77 & -550.35 & 16.54 \\
& $(0.18)$ & $(0.16)$ & $(0.66)$ \\
Constant & -155.43 & -946.33 & 324.84 \\
Sample size and adjusted $\mathrm{R}^{2}$ & $(0.29)$ & $(0.12)$ & $(0.000)$ \\
Restrictions statistic: F [5,472] & $1.53(0.18)$ & $1.73(0.13)$ & $1.24(0.29)$ \\
\hline & & &
\end{tabular}

Appendix 4: Regression analysis of baseflow using hydrological data from Manggarai watersheds.

\begin{tabular}{lcl}
\hline Baseflow (\% of Rainfall) & $\mu=42.7$ & $\sigma=8.47$ \\
Description of explanatory variable & $\beta$ (coefficient) & \begin{tabular}{l}
$\sigma$-value \\
\hline Forest cover (acres)
\end{tabular} \\
Rainfall (mm) & 0.005 & 0.003 \\
Slope (degrees) & -0.023 & 0.000 \\
Forest cover (\% of watershed) & 0.149 & 0.156 \\
Forest cover ${ }^{2} \%$ of watershed) & -0.336 & 0.112 \\
Constant & 0.002 & 0.265 \\
Adjusted $\mathrm{R}^{2}$ & 103.60 & 0.000 \\
F $(3,31)$ & 0.72 & 0.000 \\
\hline
\end{tabular}

Estimated coefficient allowed exploratory simulation of baseflow increments due to park based forest cover increase by 25 per cent or 75 per cent (see table $6 \mathrm{~A}$ and $\mathrm{B}$, columns 1 and 2). 